\title{
An integrated model for building brand in food industry
}

\author{
Seyed Najomoddin Mousavi ${ }^{a^{*}}$, Vahid Nasehi Far ${ }^{\mathrm{b}}$, Zohreh Dehdashti Shahrokh ${ }^{\mathrm{b}}$ and Seyed Mohammad Taghi \\ Taghavifard $^{\mathrm{c}}$
}

${ }^{a}$ PhD student, Department of Management and Accounting, Allameh Tabatabai University, Tehran, Iran

${ }^{b}$ Assistant Professor, Department of Management and Accounting, Allameh Tabatabai University, Tehran, Iran

${ }^{c}$ Associate Professor, Department of Management and Accounting, Allameh Tabatabai University, Tehran, Iran

\section{H R O N I C L E}

Article history:

Received May 16, 2013

Received in revised format

12 September 2013

Accepted 24 October 2013

Available online

October 272013

Keywords:

Food industry

Brand

Brand communication

Brand position

\begin{abstract}
A B S T R A C T
This paper presents an empirical investigation on the effects of various factors on building appropriate brand in food industry. The proposed study deigns a questionnaire and distributes it among some expert who were involved in food industry. Cronbach alpha are mostly well above the minimum desirable limit of 0.7 , which validate the overall questionnaire. In addition, Pearson correlation ratios indicate that there were some positive and meaningful relationships among all components of the survey. The study implements structural equation modeling and the results indicate that brand vision influences brand position, positively. In addition, there is a positive and meaningful relationship from brand vision to product performance, from stakeholders towards brand vision as well as brand position and brand communication. The survey has also detected that brand position could influence on brand communication and product performance. In our survey, brand communication influences product and brand performance, brand distribution influences on brand performance and product influences on brand performance.
\end{abstract}

\section{Introduction}

Brand plays an important role on product development and it is always necessary to find important factors influencing brand for different purposes such as gaining more market share, customer retention, etc. (Aaker, 2004; Keller, 2008; Omar \& Ali, 2010; De Chernatony, 2010). According to Merz et al. (2009), the concepts of brand and branding have been evolving over the past several decades and the evolution has been converging on a new conceptual logic, which views brand in terms of collaborative, value co-creation activities of firms and all of their stakeholders and brand value in terms of the stakeholders' collectively perceived value-in-use. Wong and Merrilees (2008) investigated the nature and magnitude of potential advantages that accrue to firms that have a high level of brand orientation. They reported strong positive relationship between brand orientation and 
brand performance. In addition, in their survey, brand orientation also exerted another, less direct influence on performance, via brand distinctiveness while innovation mediated the effect of brand distinctiveness.

Story and Hess (2010) investigated ethical brand management by looking into different aspects of customer relationships and ethical duties. The study applied an empirical study to examine a series of hypotheses concerning the effect of customers' commitment to a brand on their behaviors towards its brand. They reported that Customers' behaviors towards a brand could change as they would be more committed to the brand. They do fewer shopping, consider fewer brands, and they are willing to pay more. Kuhn et al. (2008) recommended that amongst organizational buyers there was a much bigger emphasis on the selling organization, including its corporate brand, credibility and staff, than on individual brands and their associated dimensions. Spence and Essoussi (2010) evaluated brand identity, equity and brand management in SMEs (Kotler \& Armstrong, 2005). The study was based on the analysis of four site cases of consumer goods SMEs through in-depth interviews and associated documents. They reported that the founders' value and beliefs set the tone for the core competencies to be developed and transmitted through brand identity.

Malmelin and Hakala (2009) developed a framework model of integrative brand management through a case analysis of the international Dove campaign, which was capable of corporate communications, and contributed a thorough case analysis of the international Dove campaign. Pitt et al. (2006) introduced and evaluated new dimensions for brands and revisited the functions that brands perform and link these to the evolutionary trajectory of branding in open systems. They also argued that many open systems could represent a final phase in the evolution of corporate brands from closed to open brands. Devasagayam et al. (2010) examined the appropriateness of a brand community within an internal branding framework. They reported strong support to the need for and efficacy of internal brand communities, and provided an opportunity to test the strategic synergies of pursuing such a strategy for internal as well as external audiences. Rindell and Strandvik (2010) discussed how corporate brand images evolve in consumers' everyday life and its implications for the company's branding strategies. They concluded that corporate brand evolution could be a way of including consumers' everyday brand image constructions in a company's branding strategy.

\section{The proposed model}

The proposed model of this paper presents an integrated framework to build a conceptual model for building a brand in food industry. Fig. 1 demonstrates details of our proposed model,

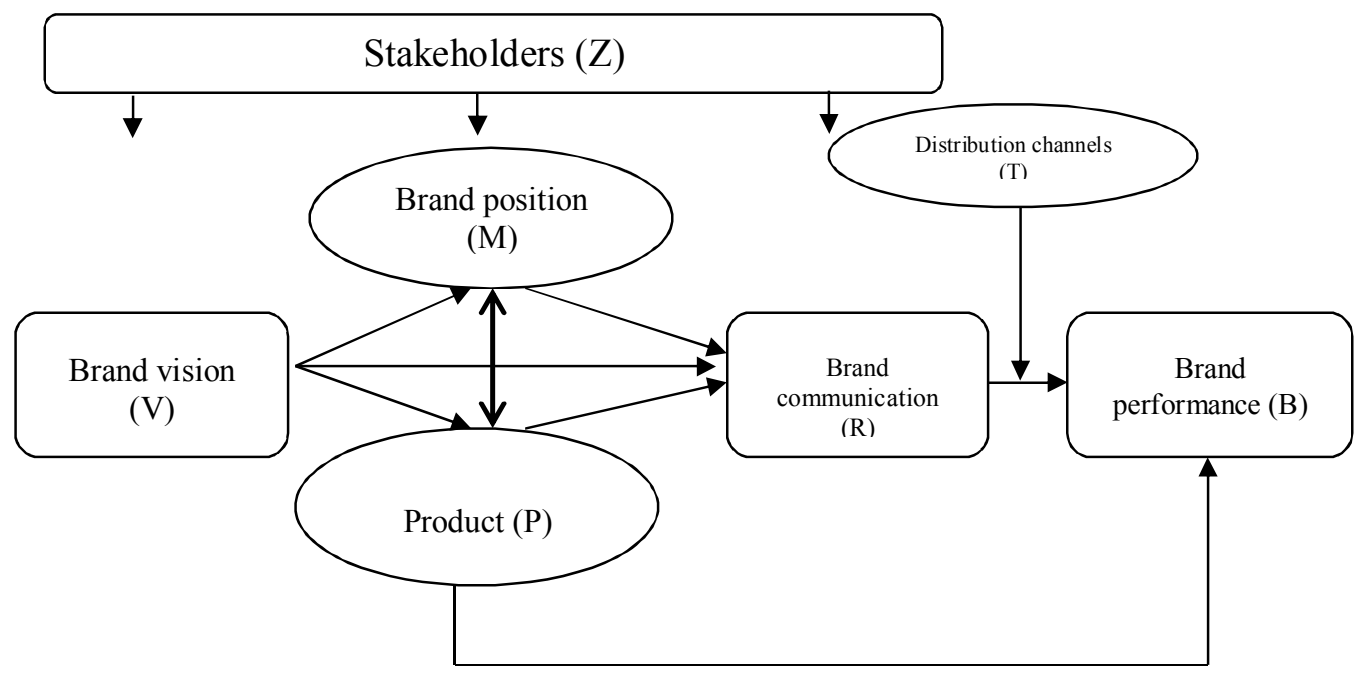

Fig. 1. The proposed study 
According to Fig. 1, brand vision, influences on brand position, product itself and brand communication. Brand position is considered in terms of customer's benefits as well as customer's perception and it influences brand communication. Product is another component of this model, which is considered in terms of characteristics as well as technical and production methods. Stakeholders are either from inside firm or from outside firm. Communication channels include marketing communications, building internal brands and preparing a good image. Finally, distribution channels include independent distribution ones as well as inside firm. The proposed study of this paper uses structural equation modelling (SEM) to measure the relationships among different components demonstrated in Fig. 1 in Iranian food industry. The proposed study designed a questionnaire and distributed it among some experts who worked for various well-known brands in food industries in Iran. We also use Pearson correlation ratios to measure the effects of various factors. The sample size is calculated as follows,

$$
n=\frac{N \times z_{\alpha / 2}^{2} \times p \times q}{\varepsilon^{2} \times(N-1)+z_{\alpha / 2}^{2} \times p \times q},
$$

where $N$ is the population size, $p=1-q$ represents the yes/no categories, $z_{\alpha / 2}$ is CDF of normal distribution and finally $\varepsilon$ is the error term. Since we have $p=0.5, z_{\alpha / 2}=1.96$ and $N=330$, the number of sample size is calculated as $n=178$ (Strauss \& Corbin, 1998). We first look at the Pearson correlation among different compoents of the survey, which are summarized in Table 1 as follows,

Table 1

The summary of Pearson correlation ratios

\begin{tabular}{cccccccc}
\hline & $\mathrm{V}$ & $\mathrm{Z}$ & $\mathrm{M}$ & $\mathrm{P}$ & $\mathrm{R}$ & $\mathrm{T}$ & $\mathrm{B}$ \\
\hline $\mathrm{V}$ & 1 & & & & & & \\
$\mathrm{Z}$ & 0.612 & 1 & & & & & \\
$\mathrm{M}$ & 0.681 & 0.49 & 1 & & & & \\
$\mathrm{P}$ & 0.404 & 0.34 & 0.556 & 1 & & & \\
$\mathrm{R}$ & 0.683 & 0.624 & 0.503 & 450 & 1 & & \\
$\mathrm{~T}$ & 0.654 & 0.572 & 0.475 & 0.398 & 0.584 & 1 & \\
$\mathrm{~B}$ & 0.777 & 0.506 & 0.672 & 0.56 & 0.689 & 0.601 & 1 \\
\hline
\end{tabular}

The results of Table 1 clearly indicate that there were strong relationships between different components of the survey. In addition, Table 2 shows details of Cronbach alphas (Cronbach, 1951) as well as AVR ratios. According to the results of Table 2, all Cronbach alphas are well above the minimum acceptable level of 0.70 .

Table 2

The summary of Cronbach alpha

\begin{tabular}{cccc}
\hline Hidden variables & AVE & $\mathrm{R}^{2}$ & Cronbach alpha \\
\hline V & 0.479 & 0.375 & 0.861 \\
Z & 0.462 & 0 & 0.792 \\
M & 0.405 & 0.472 & 0.836 \\
P & 0.344 & 0.31 & 0.879 \\
R & 0.355 & 0.562 & 0.939 \\
T & 0.435 & 0 & 0.778 \\
B & 0.33 & 0.534 & 0.797 \\
\hline
\end{tabular}




\section{The results}

In this section, we present details of our findings on testing the effects of various factors on building brand. Fig. 2 demonstrates the results of the implementation of SEM.

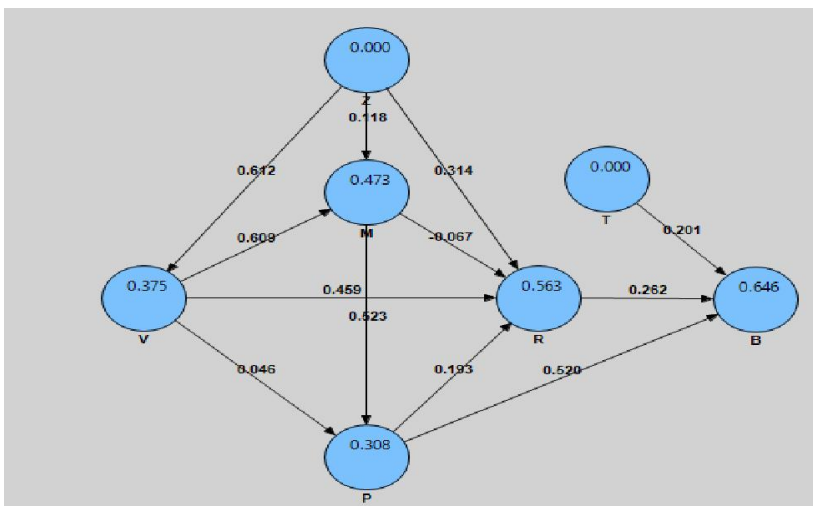

Standard coefficients

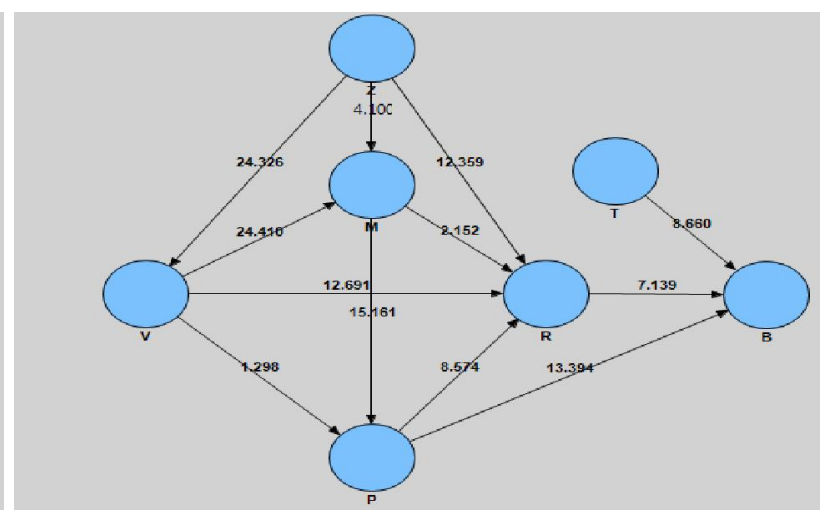

t-values

Fig. 2. The results of standard coefficients and t-values on the SEM implementation

One the left side of the figure, we observe the coefficients of various paths while on the right side we observe the results of t-student values. We have summarized the results of our survey in Table 3 as follows,

Table 3

The summary of various components

\begin{tabular}{|c|c|c|c|c|}
\hline Hypothesis & Path & Coefficient & t student & Result \\
\hline 1 & brand vision $\rightarrow$ brand position & 0.609 & $24.41 * *$ & $\sqrt{ }$ \\
\hline 2 & brand vision $\rightarrow$ brand performance & 0.046 & 1.29 & $x$ \\
\hline 3 & brand vision $\rightarrow$ Product performance & 0.45 & $12.69 * *$ & $\sqrt{ }$ \\
\hline 4 & stakeholders $\rightarrow$ brand vision & 0.61 & $24.32 * *$ & $\sqrt{ }$ \\
\hline 5 & stakeholders $\rightarrow$ brand position & 0.118 & $4.10 * *$ & $\sqrt{ }$ \\
\hline 6 & stakeholders $\rightarrow$ brand communication & 0.31 & $12.35^{* *}$ & $\sqrt{ }$ \\
\hline 7 & brand position $\rightarrow$ brand communication & -0.067 & $2.15^{*}$ & $\sqrt{ }$ \\
\hline 8 & brand position $\rightarrow$ product performance & 0.52 & $15.16^{* *}$ & $\sqrt{ }$ \\
\hline 9 & brand communication $\rightarrow$ product & 0.193 & $8.57 * *$ & $\sqrt{ }$ \\
\hline 10 & brand communication $\rightarrow$ brand performance & 0.26 & $7.13^{* *}$ & $\sqrt{ }$ \\
\hline 11 & brand distribution $\rightarrow$ brand performance & 0.201 & $8.66^{* * *}$ & $\sqrt{ }$ \\
\hline 12 & product $\rightarrow$ brand performance & 0.52 & $13.39 * *$ & $\sqrt{ }$ \\
\hline
\end{tabular}

\section{Significant with $\alpha=5 \%$}

Significant with $\alpha=1 \%$

As we can observe from the results of Table 3, except one case, the effect of brand vision on brand performance, other components are significance.

\section{Discussion and Conclusion}

In this paper, we have presented an empirical investigation to study the effects of various factors on building brand in Iranian food industry. The proposed study has determined that brand vision influences brand position, positively. In addition, there was a positive and meaningful relationship from brand vision to product performance, from stakeholders towards brand vision as well as brand position and brand communication. The survey has also detected that brand position could influence on brand communication and product performance. In our survey, brand communication influences 
product and brand performance, brand distribution influenced on brand performance and product influenced on brand performance. Based on the results of this survey, it is suggested that food industry try to penetrate into market by expanding the operations inside the cities by establishing various agencies. This would help industry introduce the products and services to more people and help consumers become familiar with different characteristics of products. There are also many studies on detecting clustering important factors on brand loyalty. Izadi Manesh and Hozouri (2013), for instance, performed an investigation of the role of brand image on consumer loyalty using factor analysis and detected six factors including penetration strategy, infrastructure characteristics, competitive pricing, target marketing strategy, communication strategy and market characteristics. As an extension to this study, we recommend interested readers to use factor analysis on detecting different factors influencing brand loyalty in food industry.

The results of our survey are consistent with similar studies published earlier (De Chernatony, 2010; Keller, 2008). However, we need to examine the results of this investigation on other industries before making some general conclusion. Fig. 3 shows structure of the confirmed model.

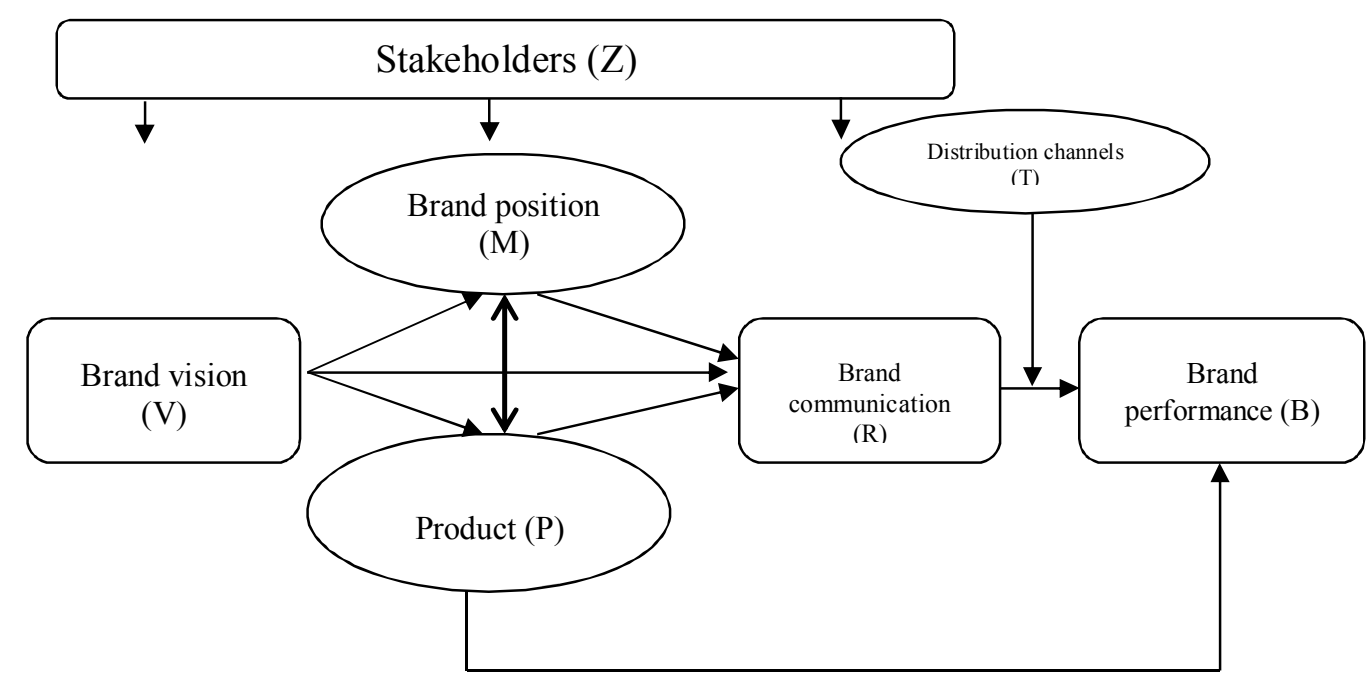

Fig. 3. The final model

\section{Acknowledgement}

The authors would like to deeply thank the experts in food industry who cordially cooperated with an accomplishment of this survey. We are also grateful for constructive comments on earlier version of this paper, which contributed on the quality of the paper.

\section{References}

Aaker, D. A. (2004). Brand portfolio Strategy: Creating Relevance, Differentiation, Energy, Leverage and Clarity. New York, Free Press.

Cronbach, L. J. (1951). Coefficient alpha and the internal structure of tests. Psychometrika, 16(3), 297-334.

De Chernatony L. (2010). From Brand Vision to Brand Evaluation: The Strategic Process of Growing and Strengthening Brands. $3^{\text {nd }}$ ed. Oxford: Published by Elsevier Ltd.

Devasagayam, P. R., Buff, C. L., Aurand, T. W., \& Judson, K. M. (2010). Building brand community membership within organizations: a viable internal branding alternative?. Journal of Product \& Brand Management, 19(3), 210-217. 
Izadi Manesh, F., \& Hozouri, S. (2013). An investigation of the role of brand image on consumer loyalty. Management Science Letters, 3(11), 2699-2704.

Keller, K.L. (2008). Strategic Brand Management. Building, Measuring, and Managing Brand Equity, $3{ }^{\text {rd }}$ ed., Pearson Prentice-Hall.

Kotler, P., \& Armstrong, G. (2005). Principles of Marketing. $10^{\text {th }}$ ed., Pearson,

Kuhn, K. A. L., Alpert, F., \& Pope, N. K. L. (2008). An application of Keller's brand equity model in a B2B context. Qualitative Market Research: An International Journal, 11(1), 40-58.

Malmelin, N., \& Hakala, J. (2009). Guided by the brand: from brand management to integrative corporate communications. Business Strategy Series, 10(5), 248-258.

Merz, M. A., He, Y., \& Vargo, S. L. (2009). The evolving brand logic: a service-dominant logic perspective. Journal of the Academy of Marketing Science, 37(3), 328-344.

Omar, M. W., \& Ali, M. N. M. (2010). Managing brand equity among Langkawi's (SMEs) independent hoteliers. International Journal of Marketing Studies, 2(1), P147.

Pitt, L. F., Watson, R. T., Berthon, P., Wynn, D., \& Zinkhan, G. (2006). The penguin's window: Corporate brands from an open-source perspective. Journal of the Academy of Marketing Science, 34(2), 115-127.

Rindell, A., \& Strandvik, T. (2010). Corporate brand evolution: corporate brand images evolving in consumers' everyday life. European Business Review, 22(3), 276-286.

Spence, M., \& Essoussi, L. H. (2010). SME brand building and management: an exploratory study. European Journal of Marketing, 44(7/8), 1037-1054.

Story, J., \& Hess, J. (2010). Ethical brand management: customer relationships and ethical duties. Journal of Product \& Brand Management, 19(4), 240-249.

Strauss, A. \& Corbin, J. (1998). Basics of qualitative research. Newbury Park, CT:Sage.

Wong, H. Y., \& Merrilees, B. (2008). The performance benefits of being brand-orientated. Journal of Product \& Brand Management, 17(6), 372-383. 